\title{
Arachidonic Acid as a Possible Negative Feedback Inhibitor of Nicotinic Acetylcholine Receptors on Neurons
}

\author{
Sukumar Vijayaraghavan, Bo Huang, Edward M. Blumenthal, and Darwin K. Berg \\ Department of Biology, University of California at San Diego, La Jolla, California 92093-0357
}

Neuronal acetylcholine receptors, being highly permeable to calcium, are likely to regulate calcium-dependent events in neurons. Arachidonic acid is a membrane-permeant second messenger that can be released from membrane phospholipids by phospholipases in a calcium-dependent manner. We show here that activation of neuronal acetylcholine receptors triggers release of ${ }^{3} \mathrm{H}$-arachidonic acid in a calcium-dependent manner from neurons preloaded with the fatty acid. Moreover, low concentrations of arachidonic acid reversibly inhibit the receptors and act most efficiently on receptors likely to have the highest permeability to calcium, namely receptors containing $\alpha 7$ subunits. Low concentrations of arachidonic acid also reversibly inhibit $\alpha 7$ containing receptors expressed in Xenopus oocytes following injection of $\alpha 7$ cRNA. The oocyte results indlcate that the inhibition is a feature of the receptors rather than a consequence of neuron-specific machinery. The inhibition is not mediated by specific metabolites of arachidonic acid because the effects can be mimicked by other fatty acids; their effectiveness correlates with their content of double bonds. In contrast to arachidonic effects on calcium currents, inhibition of neuronal nicotinic receptors by the fatty acid cannot be prevented by blocking production of free radicals or by inhibiting proteln kinase $\mathrm{C}$. An alternative mechanism is that arachidonic acid binds directly to the receptors or perturbs the local environment in such a manner as to constrain receptor function. The findings indicate that neuronal acetylcholine receptors, by virtue of their ability to elevate intracellular calcium levels, can release arachidonic acid which is likely to produce a number of secondary effects including feedback inhibition of the receptors.

[Key words: arachidonic acid, nicotinic receptors, neuronal ACh receptors, ciliary ganglion neurons, ion channels, negative feedback]

\footnotetext{
Received Sept. 30, 1994; revised Nov. 16, 1994; accepted Nov. 22, 1994.

We thank Everardo Gutierrez, Leticia Oliva, Michael Silverberg, and Terri Yuen for preparing the ciliary ganglion cell cultures, and Brian Scott for preparing the Xenopus oocytes. The chicken $\alpha 7$ full-length construct used to generate RNA for expression in oocytes was kindly provided by Dr. Ralf Schoepfer (University of Heidelberg). Grant support was provided by the National Institutes of Health (Grants R01 NS12601 and P01 NS25916), the California Affiliate of the American Heart Association (to S.V.), and the California Tobacco Related-Disease Research Program. B.H. is a Fellow of the Muscular Dystrophy Association; E.M.B. is a Fellow of the California Tobacco Related-Disease Research Program.

Correspondence should be addressed to Darwin K. Berg, Department of B $\mathrm{A}$ ology, 0357, University ol California, San Diego, 9500 Gilnan Drive, La Jolla, CA 92093-0357.

Copyright (C) 1995 Society for Neuroscience $0270-6474 / 95 / 153679-09 \$ 05.00 / 0$
}

Nicotinic acetylcholine receptors (AChRs) are widely distributed in the vertebrate nervous system (for review see Sargent, 1993). The receptors can function as postsynaptic receptors mediating, for example, fast excitatory transmission between preganglionic nerve terminals and autonomic neurons as well as excitatory transmission between axon collaterals of motoneurons and Renshaw cells in the spinal cord. Increasing evidence indicates that neuronal AChRs also serve a presynaptic function, modulating neurotransmitter release from axon terminals (Clarke and Pert, 1985; Schulz and Zigmond, 1989; Rapier et al., 1990; Mulle et al., 1991; Lena et al., 1993; Van der Kloot, 1993). The maintenance of some AChR subtypes in predominantly nonsynaptic locations on neurons in adults suggests the possibility of yet other roles (Jacob and Berg, 1983; Loring et al., 1985). Despite the abundance of such receptors and their potential for cell-cell signaling, relatively little is known about the regulation of $A C h R$ function on neurons.

A feature of neuronal AChRs likely to contribute both to cell signaling capabilities and to self-regulation is their high permeability to calcium (Fieber and Adams, 1991; Sands and Barish, 1991; Galzi et al., 1992; Mulle et al., 1992; Vernino et al., 1992; Seguela et al., 1993; Trouslard et al., 1993). Elevation of intracellular free calcium levels either directly or indirectly by neuronal AChRs has been cited as a mechanism by which the receptors trigger such diverse events as calcium-dependent currents (Mulle et al., 1992; Vernino et al., 1992), neurite retraction (Chan and Quik, 1993; Pugh and Berg, 1994), and expression of early genes in neurons and PCl 2 cells (Greenberg et al., 1986). Possible effects of calcium influx on neuronal AChR function have received less attention.

One mechanism by which AChR-mediated increases in calcium levels could influence many cellular events is through the production of arachidonic acid (AA). AA is released from membrane phospholipids in a calcium-dependent manner by phospholipase $\mathrm{A}_{2}$ and by phospholipase $\mathrm{C}$ followed by diacylglycerol lipase. The compound and its metabolites can act as membranepermeant second messengers, and have been proposed as transynaptic modulators of neurotransmitter release as well as regulators of several ionic currents (Piomelli et al., 1987; Kim and Clapham, 1989; Ordway et al., 1989, 1991; Keyser and Alger, 1990; Piomelli and Greengard, 1990; Schweitzer et al., 1990; Harish and Poo, 1992; Shimada and Somlyo, 1992; Fraser et al., 1993). Activation of $N$-methyl-D-aspartate (NMDA) receptors on striatal neurons can induce production of AA (Dumuis et al., 1988). In what may represent a positive feedback loop, AA has been shown to potentiate the current responses of NMDA receptors in isolated cerebellar granule cells (Miller et al., 1992).

Chick ciliary ganglion neurons offer a system for testing 
whether activation of neuronal $\Lambda C h R$ s induces $\Lambda \Lambda$ release, and for determining the effects of $\mathrm{AA}$ on receptor function. The neurons have two major classes of AChRs. One class is primarily synaptic in location, binds the monoclonal antibody ( $\mathrm{mAb}$ ) 35, and contains, as a population, the $\alpha 3, \beta 4$, and $\alpha 5$ AChR gene products (Ravdin and Berg, 1979; Jacob et al., 1984; Loring et al., 1984; Halvorsen and Berg, 1987; Loring and Zigmond, 1987; Vernallis et al., 1993). The receptors, termed here mAb 35-AChRs, are responsible for chemical synaptic transmission through the ganglion. The second class of receptors is $5-10$-fold more abundant, binds $\alpha$-bungarotoxin $(\alpha \mathrm{Bgt})$, and is located primarily in nonsynaptic regions on the neurons (Chiappinelli and Giacobini, 1978; Jacob and Berg, 1983; Loring et al., 1985). The receptors, termed $\alpha$ Bgt-AChRs, contain only $\alpha 7$ of the known neuronal AChR gene products and function as ligand-gated ion channels, though their physiological role in the ganglion is unclear (Vernallis et al., 1993; Zhang et al., 1994). Both classes of receptors can elevate intracellular calcium levels in the neurons (Vijayaraghavan et al., 1992).

We report here that activation of AChRs on ciliary ganglion neurons releases AA. Moreover, micromolar concentrations of AA reversibly block nicotine-induced currents in the neurons, inhibiting both $\alpha \mathrm{Bgt}-\mathrm{AChRs}$ and mAb 35-AChRs. The blockade suggests that AA may serve as a negative feedback regulator of nicotinic responses in neurons.

\section{Materials and Methods}

Cell preparations. For experiments involving release of AA, chick ciliary ganglion neurons were dissociated from $8 \mathrm{~d}$ embryos and maintained in cell culture (8-10 dissociated ganglia per $35 \mathrm{~mm}$ dish) for 6 d as previously described (Nishi and Berg, 1981). For experiments in volving electrophysiological recordings, ciliary ganglion neurons were dissociated from 14-15-d-old embryos, allowed to settle on a substratum of poly-D-lysine, and used on the same day as previously described (Margiotta and Gurantz, 1989; Zhang et al., 1994).

$A A$ release. Neuronal cultures were incubated overnight with $1 \mu \mathrm{Ci}$ ${ }^{3} \mathrm{H}-\mathrm{AA}$ (180-240 Ci/mmol; Dupont-New England Nuclear Research Products) to label the cells, and then were rinsed five times with $10 \mathrm{~mm}$ HEPES, $\mathrm{pH} 7.4$, containing $0.5 \mathrm{mg} / \mathrm{ml}$ BSA and Eagle's MEM salts without bicarbonate (rinse medium) warmed to $37^{\circ} \mathrm{C}$. After incubating the cells an additional $20 \mathrm{~min}$ at $37^{\circ} \mathrm{C}$ in rinse medium or MEM containing bicarbonate, they were incubated in a fresh change of rinse medium $(0.5 \mathrm{ml})$ containing the indicated concentrations of nicotine or KCl. Five minutes later, unless otherwise indicated, the medium was removed and analyzed for radioactivity by scintillation counting to determine the amount of label released from the cells. The cells were then scraped in $100 \mu \mathrm{l}$ of $0.5 \mathrm{~N} \mathrm{NaOH}$, neutralized, and analyzed for radioactivity to determine the amount of label remaining with the cells. Usually $0.5 \mathrm{ml}$ aliquots were mixed with $10 \mathrm{ml}$ of EcoLite (ICN Biomedicals) for scintillation counting. Specific release of radioactive material into the culture medium was calculated as the difference in the amount of radioactivity found in the medium of cultures incubated with and without the secretogog, either nicotine or $\mathrm{KCl}$. The amount released was expressed as a percent of the total radioactivity initially associated with the cells (calculated as the sum of the label remaining with the cells at the end of the incubation and the amount released into the medium). Total radioactivity initially associated with the cells averaged $3.5 \pm 0.1 \times 10^{5} \mathrm{cpm}$ per culture (mean $\pm \mathrm{SEM}, n=126$ cultures) Nonspecific release was measured in each experiment and was subtracted from the values shown. In some cases released products were analyzed by performing chloroform extractions of the release media, concentrating the extracts under nitrogen, and running them on thin layer chromatograms using petroleum ether/diethyl ether/acetic acid (100:50: $1, \mathrm{v} / \mathrm{v}$ ) as the solvent system (Lax et al., 1990).

The total amount of AA released from ciliary ganglion neurons by nicotinic stimulation was estimated by assuming it was comparable to that released specifically per milligram of protein by activation of NMDA receptors in hippocampal slices ( $1 \mathrm{nmol} / \mathrm{mg}$ ) during a similar time period (2.5 min; Clements et al., 1991). [Ciliary ganglion neurons in culture actually release a larger proportion of incorporated ${ }^{3} \mathrm{H}-\mathrm{AA}$ in response to nicotine than do hippocampal neurons through activation of NMDA receptors (Sanfeliu et al., 1990).] The amount of membrane protein per embryonic day 14 ciliary ganglion was taken to be $5 \mu \mathrm{g}$ (Chiappinelli et al., 1976) when calculating AA release. The mean diameter of ciliary ganglion neurons for calculating cell volume was taken to be $20 \mu$ in.

Whole-cell patch-clamp recordings. Whole-cell voltage-clamp measurements (Hamill et al., 1981) were performed on freshly dissociated chick ciliary ganglion neurons as previously described ('Lhang et al., 1994). The patch pipettes used were pulled from $1.5 \mathrm{~mm}$ o.d. borosilicate glass (Garner glass) and had resistances of $1-1.5 \mathrm{M} \Omega$ when filled with intracellular solution containing (mM) $145 \mathrm{CsCl}, 1.2 \mathrm{MgCl}_{2}, 5$ HEPES, pH 7.2, 10 EGTA, and 15 glucose. Cells were perfused with extracellular solution containing (mM) $150 \mathrm{NaCl}, 3 \mathrm{KCl}, 2 \mathrm{CaCl}_{2}, 2$ $\mathrm{MgCl}_{2}, 5$ glucose, and 10 HEPES (pH 7.4). Series resistance compensation of $80 \%$ was used in all experiments, and cells with series resistance exceeding $5 \mathrm{M} \Omega$ were excluded. An Axopatch $1 \mathrm{C}$ amplifier (Axon Instruments) was used for the whole-cell voltage clamp. Cells were held at $-60 \mathrm{mV}$.

Compounds were applied from a linear array of glass tubes $(250 \mu \mathrm{m}$ i.d., $350 \mu \mathrm{m}$ o.d.; Polymicro Technologies) mounted on a Leitz manipulator. A set of solenoid valves (Neptune Research) was used to control flow from the tubes by gravity feed. Tubes containing drug solutions were closed unless in use. Immediately before use, the tube tips were cleared by moving the pipette array away from the cell, opening the switch briefly, and then quickly repositioning the tips within $200 \mu \mathrm{m}$ of the cell before opening the appropriate valve again. Nicotine (10 $\mu \mathrm{M})$ was applied for $2 \mathrm{sec}$ at 1-2 min intervals; when indicated, AA and other fatty acids were applied for $10 \mathrm{sec}$ immediately prior to nicotine application.

Currents were recorded on videotape (Neuro-Corder DR-390 with Panasonic AG-1260 VCR). The data were filtered at $0.5-1 \mathrm{kHz}$ and digitized at $1-2 \mathrm{kHz}$ with the pCLAMP program (Axon Instruments). AXOGRAPH software (version 1.01, Axon Instruments) was used to measure whole-cell currents and perform exponential fits as described in Zhang et al. (1994).

Stock solutions of AA (Calbiochem) and other fatty acids (Sigma) were prepared in ethanol. Prior to each experiment, an appropriate amount of the stock solution was transferred to a glass tube. The ethanol was evaporated under nitrogen and the fatty acids were immediately suspended in the extracellular solution by brief $(30 \mathrm{sec})$ sonication. $\mathrm{H}-7$ (Calbiochem) and SOD (Worthington Enzymes) were each diluted from aqueous stocks using intracellular recording solution.

Two-electrode voltage-clamp recordings. Two-electrode voltageclamp recording techniques were used on Xenopus oocytes expressing $\alpha 7$-containing receptors. The $\alpha 7$ cRNA was transcribed from the chick brain $\alpha 7$ cDNA construct pCH2934-SP6 (Schoepfer et al., 1990) using a transcription kit (mMessage mMachine from Ambion). Xenopus oocytes were injected with approximately $10 \mathrm{ng}$ of the $\alpha 7 \mathrm{cRNA}$ and tested for ACh responses 3-5 d later. Two-electrode voltage-clamp measurements were performed as described (Ballivet et al., 1988) using an OC 725A amplifier (Warner Instruments). Current and voltage electrodes were filled with $3 \mathrm{M} \mathrm{KCl}$ and had resistances of $0.5-2 \mathrm{M} \Omega$ Oocytes were held at $-80 \mathrm{mV}$. Perfusion of the oocytes in the recording chamber was achieved by gravity feed at the rate of $8-10 \mathrm{ml}$ per minute with recording solution containing $(\mathrm{mM}) 85 \mathrm{NaCl}_{2} 2.5 \mathrm{KCl}, 2 \mathrm{CaCl}_{2}$ (or $\mathrm{BaCl}_{2}$ as indicated), 0.0005 atropine, and $10 \mathrm{HEPES}, \mathrm{pH} 7.4 . \mathrm{ACh}, \mathrm{AA}$, and other fatty acids were diluted in recording solution as described above.

Currents were recorded directly with a chart recorder or captured on videotape using a VR 10B digital data recorder (Instrutech) with a Sony SV0 1410 VCR. Data were filtered at $100 \mathrm{~Hz}$ and digitized at $170 \mathrm{~Hz}$ with the pCLAMP program. Analysis of the currents was carried out as described above for whole-cell patch-clamp recordings.

Materials. White Leghorn chick embryos were obtained locally and maintained at $37^{\circ} \mathrm{C}$ in a humidified incubator. Frogs were obtained from NASCO (Fort Atkinson. WI). $\alpha$ Bgt was purified from Bungarus multicinctus venom (Ravdin and Berg, 1979). All other compounds were purchased from Sigma unless otherwise indicated.

\section{Results}

Nicotine-induced AA release from neurons. 'The ability of AChRs to trigger AA release in neurons was tested by incubat- 
A

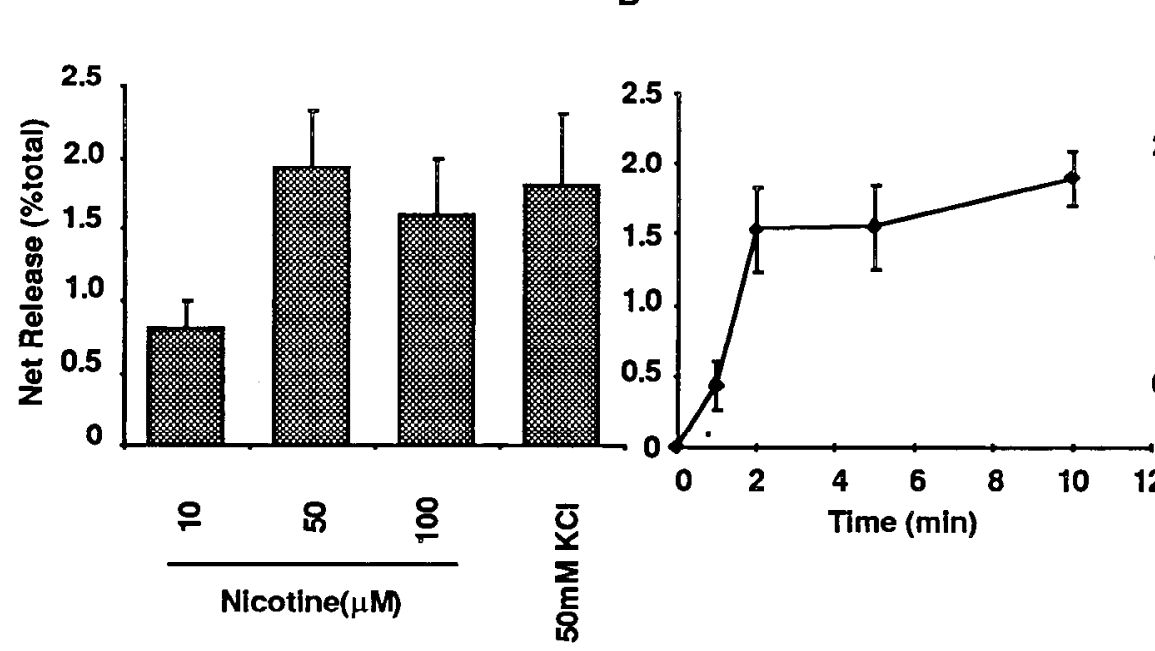

C

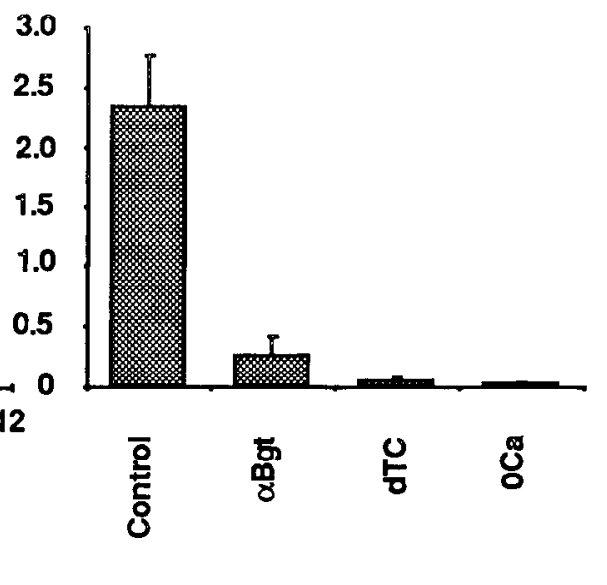

Figure 1. Nicotine-induced release of ${ }^{3} \mathrm{H}-\mathrm{AA}$ from neurons in culture. Ciliary ganglion neurons from $8 \mathrm{~d}$ embryos were grown for $6 \mathrm{~d}$ in culture and then incubated overnight in $1 \mu \mathrm{Ci}{ }^{3} \mathrm{H}$-AA, rinsed, and used to examine ${ }^{3} \mathrm{H}$-AA release. $A$, Concentration dependence of nicotine-induced release. Labeled neurons were incubated with the indicated concentration of nicotine or $50 \mathrm{~mm}$ potassium for 5 min, and the amount of radioactivity released into the medium was determined and expressed as a percent of the total initially associated with the cells. Values represent the mean $\perp$ SEM of 6-14 cultures pooled from three to five separate experiments. $B$, Time course of nicotine-induced release. Labeled neurons were incubated with $50 \mu \mathrm{M}$ nicotine for the indicated times, and the released radioactivity was then determined and expressed as in $A$. Corresponding basal release was subtracted from each time point. Values represent the mean \pm SEM of four cultures per time point from two experiments. $C$, Blockade of nicotine-induced release. Labeled neurons were incubated in the indicated test conditions prior to and during a 5 min exposure to $50 \mu \mathrm{M}$ nicotine. Radioactivity released into the medium was then quantified. Control, no blockers; $\alpha B g t, 60 \mathrm{nM} \alpha \mathrm{Bgt}$ for $40 \mathrm{~min} ; d T C, 20 \mu \mathrm{M} \mathrm{d}-\mathrm{tubocurarine}$ for $5 \mathrm{~min} ; O C \mathrm{Ca}, 0.5 \mathrm{mM}$ EGIA in place of the calcium normally present in the medium. Values represent the mean \pm SEM of $6-11$ cultures from three experiments. Total mean radioactivity associated with the neurons at the outset of the release period was $3.5 \pm 0.1 \times 10^{5} \mathrm{cpm} / \mathrm{culture}(\mathrm{mean}$ $\pm \mathrm{SEM}, n=126$ cultures). Nonspecific release was about $1 \%$ of the total $(1.15 \pm 0.06 \%$, mean \pm SEM, $n=29$ cultures) and was not changed by cholinergic antagonists or removal of extracellular calcium (basal release of $0.9 \pm 0.1 \%, 1.1 \pm 0.1 \%$, and $1.0 \pm 0.1 \%$ in the presence of d-tubocurarine, $\alpha$ Bgt, and $0 \mathrm{~mm}$ extracellular calcium, respectively). Specific release was significant $(p<0.05$ by the two-tailed paired $t$ test) for all cases in $A$, for the 5 and 10 min points in $B$, and for the control in $C$.

ing ciliary ganglion neurons in culture with ${ }^{3} \mathrm{H}-\mathrm{AA}$ overnight, rinsing the cells, and then challenging them with nicotine (Fig. $1 A)$. At $50 \mu \mathrm{M}$, nicotine induced a net release of $2.0 \pm 0.3 \%$ (mean $\pm \mathrm{SEM}, n=25$ cultures from nine experiments; $p<$ 0.0001 ) of the total radioactivity associated with the cells. At 10 $\mu \mathrm{M}$, nicotine caused a smaller but significant amount of release, while $100 \mu \mathrm{M}$ induced no more release than did $50 \mu \mathrm{M}$. Chronic depolarization of the cells with $50 \mathrm{~mm}$ potassium to trigger activation of voltage-dependent calcium channels (VDCCs) induced about the same amount of release as did 50 and $100 \mu \mathrm{M}$ nicotine.

Nicotine-induced release of ${ }^{3} \mathrm{H}$-AA was relatively rapid. Within $60 \mathrm{sec}$ of agonist application, ${ }^{3} \mathrm{H}-\mathrm{AA}$ could be detected in the culture medium, and after 2 min no further increase was observed (Fig. $1 B$ ). The release depended on both activation of AChRs and on extracellular calcium (Fig. 1C). Preincubating the neurons with $60 \mathrm{nM} \alpha \mathrm{Bgt}$ or $20 \mu \mathrm{M}$ d-tubocurarine largely blocked nicotine-induced release of ${ }^{3} \mathrm{H}-\mathrm{AA}$, indicating that $\alpha$ Bgt-AChRs played an important role. Substitution of EGTA for calcium in the extracellular medium also prevented the release. The results suggest a mechanism for ${ }^{3} \mathrm{H}-\mathrm{AA}$ release in which AChR activation elevates intracellular calcium levels (by calcium entering either directly through the receptors or indirectly through VDCCs activated by depolarization caused by the receptors), stimulating phospholipase $A_{2}$ or possibly phospholipase $\mathrm{C}$ with diacylglycerol lipase providing the final step.

The composition of radioactive components released from the neurons by nicotine was examined by chloroform extraction of the culture medium followed by thin layer chromatography. No radioactivity was recovered in the aqueous phase of the extraction. About $70 \%$ of the radioactivity was recovered during chromatography as free fatty acid, as expected for AA. Of the remaining $30 \%$, about half was recovered at the origin and probably represents prostaglandins and related derivatives (Grossman et al., 1986), while most of the rest was recovered as a trail of material following the AA sample and very likcly represents fatty acid. No detectable radioactivity chromatographed as 5-hydroxyeicosatetraenoic acid (5-HETE) or the 5 or 15 corresponding hydroperoxy derivatives (5-HPETE, 15-HPETE), three common metabolites of AA.

Effect of AA on nicotinic responses from neurons. Whole-cell patch-clamp recording techniques were used to test the effect of AA on the nicotinic responses of ciliary ganglion neurons freshly dissociated from 14-15-d chick embryos. Agonist was rapidly applied to individual neurons from a large bore micropipette to achieve activation of both $\alpha \mathrm{Bgt}-\mathrm{AChRs}$ and mAb 35-AChRs (Zhang et al., 1994). The large, rapidly decaying response observed under these conditions is exclusively generated by $\alpha \mathrm{Bgt}-$ AChRs and has a half-time of decay of about $13 \mathrm{msec}$. The slow component, with a half-time for decay of 3-4 sec, is principally the product of the mAb 35-AChRs.

Application of $1 \mu \mathrm{M}$ AA for $10 \mathrm{sec}$ from a large bore micropipette dramatically and reversibly reduced the rapidly decaying response induced by nicotine (Fig. 2). Less impact was observed on the slow response. At $20 \mu \mathrm{M}$, AA affected both types of responses. To quantify the effects of AA on $\alpha B g t-A C h R$ responses, the peak amplitude of the rapidly decaying component was measured before, during, and after exposure to AA. At 1 
Before AA

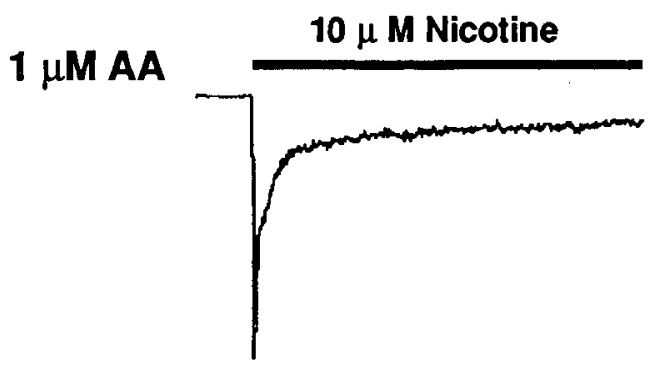

With AA

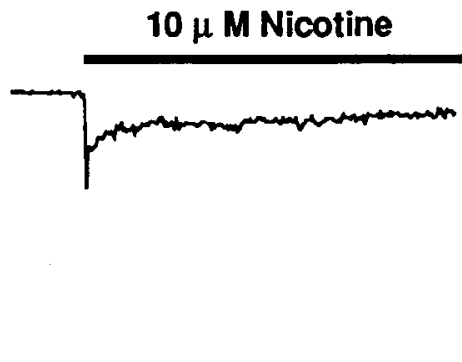

After Recovery

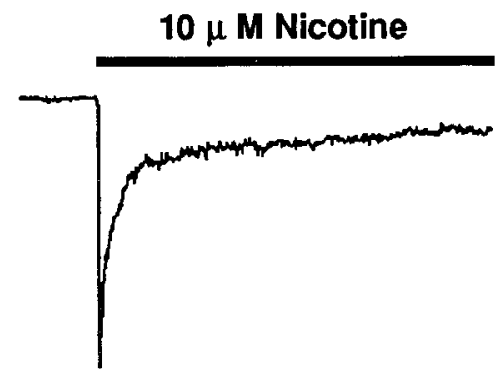

\section{$20 \mu \mathrm{M}$ AA}
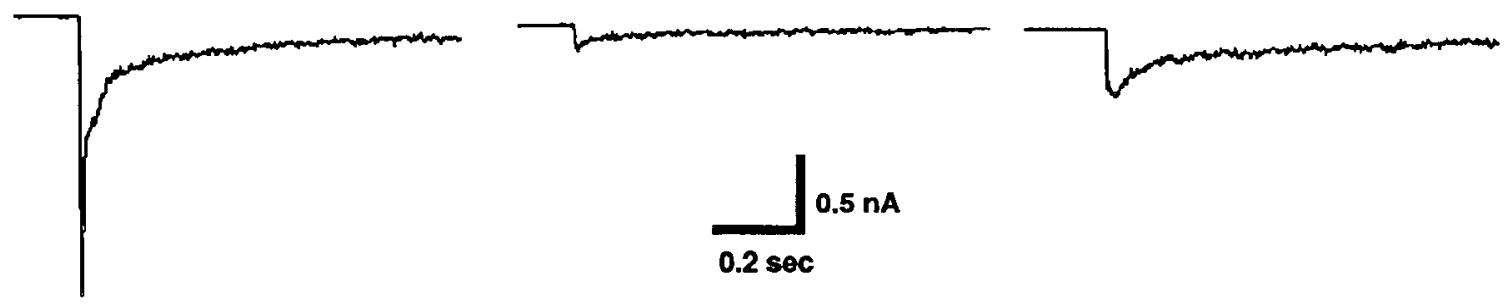

Figure 2. Effects of AA on nicotine-induced currents in ciliary ganglion neurons. Whole-cell currents induced by $10 \mu \mathrm{M}$ nicotine (horizontal bars) were measured before application (Before $A A$ ), immediately after a 10 see application (With $A A$ ), and after a 2 min rinse following application (After Recovery) of AA either at $1 \mu \mathrm{M}$ (upper row of traces) or at $20 \mu \mathrm{M}$. AA at $1 \mu \mathrm{M}$ reversibly inhibited the rapidly decaying component of the nicotine-induced current, while at $20 \mu \mathrm{M}$ it inhibited both the rapidly decaying and the more sustained components of the response.

$\mu \mathrm{M}$ AA reversibly inhibited about half of the response, while 5 $\mu \mathrm{M}$ inhibited over $90 \%$ (Fig. $3 A$ ). At higher concentrations of $\Lambda \Lambda(20 \mu \mathrm{M})$ the blockade was essentially complete and very little recovery was observed following the usual 2 min rinse period.

Measuring the amplitude of the nicotine-induced current at 1 sec indicated that $\mathrm{AA}$ also reversibly inhibited $\mathrm{mAb} 35-\mathrm{AChR}$ responses but that higher concentrations of $\mathrm{AA}$ were required. At $1 \mu \mathrm{M}$, AA had almost no effect on the mean amplitude of the current observed at $1 \mathrm{sec}$, while $20 \mu \mathrm{m}$ blocked over half of the response (Fig. $3 B$ ). Approximately a third of the whole-cell response at 1 sec represents residual $\alpha B g t-A C h R$ current, while two-thirds derives from mAb 35-AChRs (Zhang et al., 1994). Since presumably all of the $\alpha \mathrm{Bgt}-\mathrm{AChR}$ response would have been blocked by $20 \mu \mathrm{M}$ AA, the partial blockade observed at 1 sec indicates that only about half of the mAb 35-AChRs were inhibited by the concentration used. This was confirmed by testing the nicotinic responses of cells after treatment with $60 \mathrm{nM}$ $\alpha \mathrm{Bgt}$ for $2-1 \mathrm{hr}$ at $37^{\circ} \mathrm{C}$. A $10 \mathrm{sec}$ exposure to $20 \mu \mathrm{M}$ AA reduced the peak response by $43 \pm 3 \%$ (mean $\pm \mathrm{SEM}, n=$ 14 cells), as predicted for mAb 35-AChRs.

The kinetics of the AA effect were determined by measuring the peak response induced by $10 \mu \mathrm{M}$ nicotine before and after short applications of AA at low concentrations. A 2.5 sec pulse of $5 \mu \mathrm{M}$ AA achieved a sizable inhibition; extending the exposure to $15 \mathrm{sec}$ increased the inhibition further (Fig. 4A). Reversal of the inhibition was also quick. Even a $5 \mathrm{sec}$ rinse relieved part of the inhibition produced by a $10 \mathrm{sec}$ application of $5 \mu \mathrm{M} \mathrm{AA}$; within $20 \mathrm{sec}$ most of the response had recovered (Fig. $4 B$ ).

Effect of $A A$ on nicotinic responses from oocytes expressing the AChR $\alpha 7$ gene. Since ciliary ganglion $\alpha \mathrm{Bgt}$-AChRs are known to contain the $\alpha 7$ gene product, experiments were carried out to determine whether AA also blocks nicotinic receptors resulting from expression of the $\alpha 7$ gene in Xenopus oocytes. The purpose of these experiments was twofold. First, demonstrating a blockade in oocytes would indicate that it depended on the receptor rather than cellular machinery unique to the neuron. Second, the oocyte system would eliminate the possibility that the AA effect on ciliary ganglion neurons was indirect, resulting from effects on residual preganglionic synaptic boutons that might have remained attached to the dissociated neurons. If such bouton remnants adhered to the dissociated neurons, it might be argued that the AA enhanced the rate of $\mathrm{ACh}$ leakage from them in a way that promoted receptor desensitization on the neurons and masqueraded as an AA effect on the receptors.

Oocytes were injected with approximately $10 \mathrm{ng}$ of $\alpha 7 \mathrm{RNA}$ and 3-5 d later were checked for responses to $100 \mu \mathrm{M} \mathrm{ACh}$ using a two-electrode voltage clamp. (ACh was used as the natural agonist; in the case of ciliary ganglion neurons, nicotine was used because it best resolved the responses of both $\alpha \mathrm{Bgt}-$ $\mathrm{AChRs}$ and mAb 35-AChRs on the cells.) Multiple responses could be elicited from an individual oocyte without significant rundown of the signal. Application of $5 \mu \mathrm{M}$ AA for $30 \mathrm{sec}$ reduced the response of the oocytes to $8 \pm 1 \%$ (mean $\pm \mathrm{SEM}$, $n=7$ oocytes) of the initial value. An example is shown in Figure $5 A$. Rinsing the fatty acid away for 2 min allowed the ACh response to recover to $74 \pm 6 \%$ of the initial value $(n=$ 7).

Because activation of $\alpha 7$-AChRs in Xenopus oocytes allows sufficient calcium entry to activate calcium-dependent chloride currents (Seguela et al., 1993), it was important to determine whether the AA effect was exerted on receptor currents or on currents induced by the calcium entry. One method of doing this was to replace the extracellular calcium with barium since bar- 
A
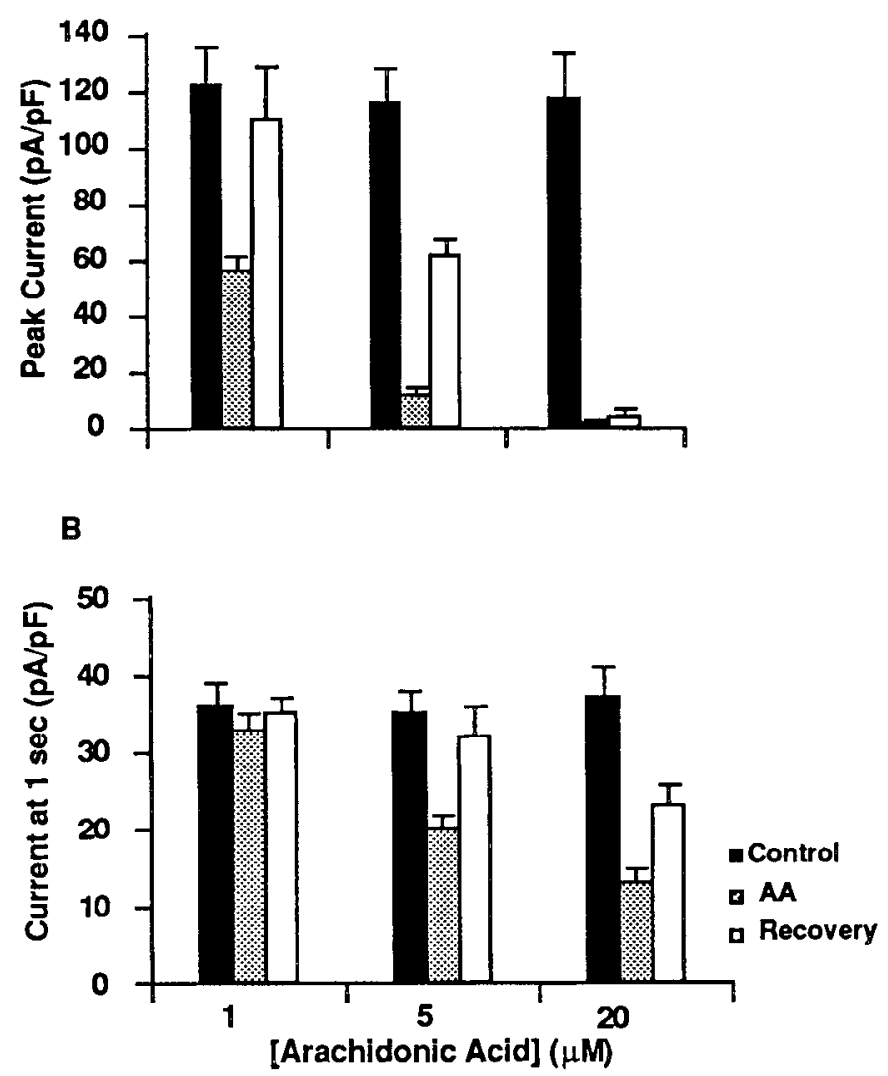

Figure 3. Concentration dependence of AA inhibition of $\alpha \mathrm{Bgt}-\mathrm{AChR}$ and $\mathrm{mAb} 35-\mathrm{AChR}$ responses. Whole-cell currents induced by $10 \mu \mathrm{M}$ nicotine in neurons before, during, and after application of the indicated concentrations of AA were recorded as described in Figure 2. A, Inhibition of $\alpha \mathrm{Bgt}-\mathrm{AChR}$ responses. The rapidly decaying peak current that arises solely fron $\alpha B g t-A C h R$ activation was measured in each of the conditions. $B$, Inhibition of $\mathrm{mAb} 35-\mathrm{AChR}$ responses. The whole-cell current present $1 \mathrm{sec}$ after initiation of the nicotine pulse was measured from the same trials as in $A$. By $1 \mathrm{sec}$, about two-thirds of the current results from $m A b 35-A C h R s$, while the remainder represents current from $\alpha \mathrm{Bgt}-\mathrm{AChRs}$. Low concentrations of AA reversibly inhibited $\alpha B$ gt-AChR responses, while higher concentrations were required to inhibit $\mathrm{mAb} 35-\mathrm{AChR}$ responses. Values were normalized for capacitance $(\mathrm{pA} / \mathrm{pF})$ and represent the mean \pm SEM of $12-17$ neurons per condition.

ium can pass through $\alpha 7$-containing receptors (Ferrer-Montiel and Montal, 1993) but causes little, if any, activation of calciumdependent chloride currents (Barish, 1983; Sands et al., 1993). In the presence of $2 \mathrm{~mm}$ barium the current amplitude was 31 $\pm 3 \%$ ( $n=9$ oocytes) of that obtained in $2 \mathrm{~mm}$ calcium. The reversal potential of the response in barium was about $30 \mathrm{mV}$ more positive than in calcium, consistent with most, if not all, of the chloride current having been lost (data not shown). Application of $5 \mu \mathrm{M} \mathrm{AA}$ for $30 \mathrm{sec}$ reduced the ACh response in barium to $25 \pm 4 \%(n=11)$ of that obtained for initial responses from the same oocytes prior to AA treatment. Values ranged from 9 to $45 \%$. Rinsing the oocytes for $2 \mathrm{~min}$ to remove the AA allowed the $\mathrm{ACh}$ response to recover to $75 \pm 5 \%(n=$ 11) of the initial response (Fig. $5 B$ ).

A dose-response curve was generated for AA by comparing the amplitude of the $\mathrm{ACh}$ response in individual oocytes in each of several AA concentrations. A maximal blockade was obtained
A

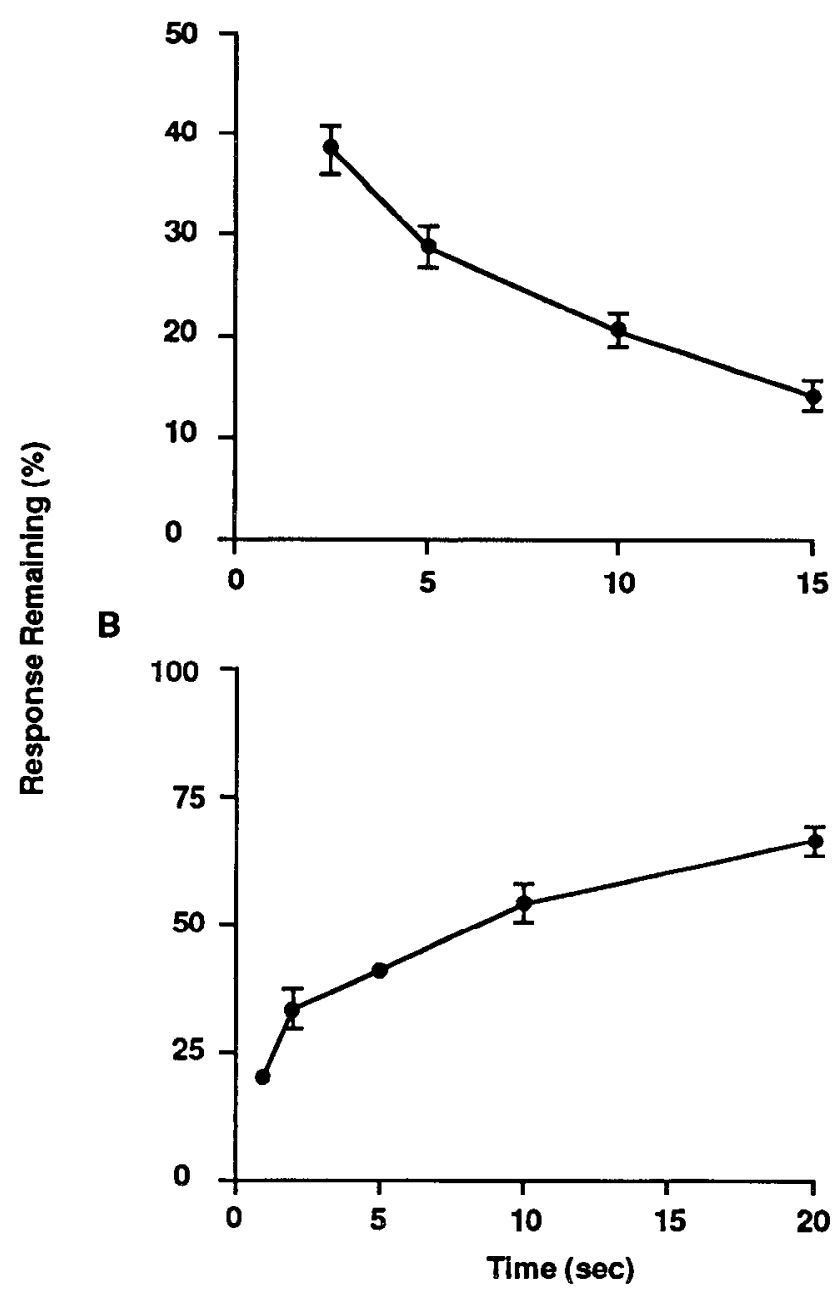

Figure 4. Kinetics of AA effects. A, Time course of onset of inhibition. AA was applied at $5 \mu \mathrm{m}$ for the indicated durations, and the wholecell response to $10 \mu \mathrm{M}$ nicotine was measured $1 \mathrm{sec}$ later. Values are expressed as a percent of the response obtained before application of $\Lambda \Lambda$ ( $1.5 \mathrm{~min}$ earlier $)$ and represent the mean \pm SEM for three to six neurons per time point. $B$, Time course for recovery from inhibition. AA was applied at $5 \mu \mathrm{M}$ for $10 \mathrm{sec}$, and the whole-cell response to 10 $\mu \mathrm{m}$ nicotine was measured after the indicated delays. Values are expressed as in $A ; n=4-15$ neurons per time point.

with a $30 \mathrm{sec}$ application of $5-10 \mu \mathrm{M}$ AA, leaving a residual $20 \%$ of the response in barium (Fig. 6). Increasing the AA concentration to $20 \mu \mathrm{M}$ did not increase the extent of blockade. Half-maximal blockade was achieved with $1 \mu \mathrm{M}$ AA.

Comparison of AA with other fatty acids. Other fatty acids were tested for their ability to mimic AA in blocking the $\mathrm{ACh}$ response of Xenopus oocytes injected with $\alpha 7$ RNA. Fatty acids were selected on the basis of structural similarity to AA and were applied for $30 \mathrm{sec}$ prior to measuring the ACh response. Fatty acids having either no double bonds (stearic acid, arachidic acid) or only one double bond in cither the cis or trans configuration (oleic acid, elaidic acid) had little or no effect on the ACh response (Fig. 7). Fatty acids having two (linoleic acid) or three (linolenic acid) double bonds produced partial inhibition but were not as effective as AA with its four double bonds. The ability of a fatty acid to inhibit the $\mathrm{ACh}$ response appears to correlate with the degree of unsaturation in the compound. 


\section{A $2 \mathrm{mM}$ Calcium}

\section{Before AA}

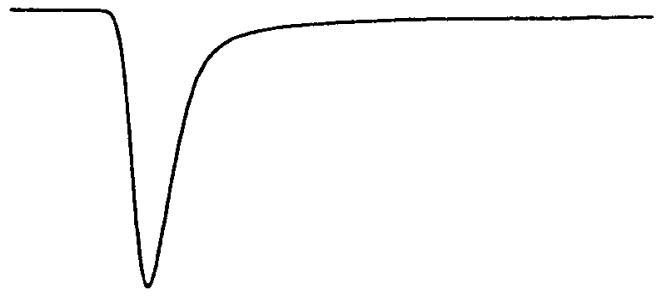

With AA

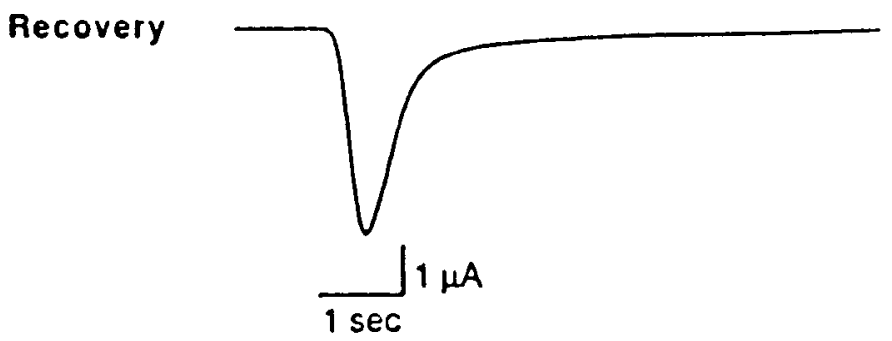

\section{B $2 \mathrm{mM}$ Barium}
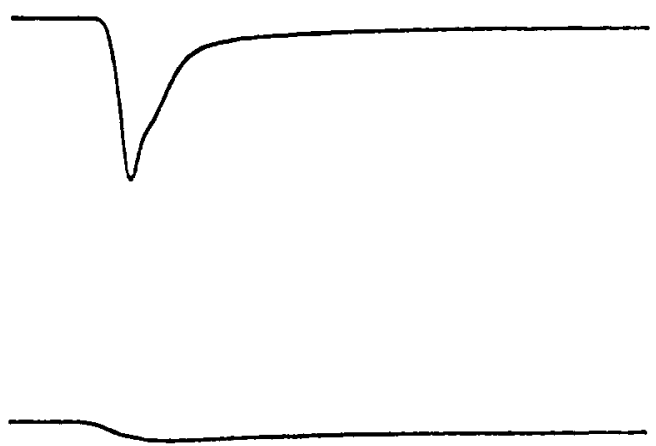

Figure 5. AA inhibition of $\alpha 7$-containing AChRs expressed in Xenopus oocytes. Oocytes injected with $\alpha 7$ RNA were stimulated with $100 \mu \mathrm{M}$ $\mathrm{ACh}$ for $5 \mathrm{sec}$ before (Before AA), during (With AA), and after (Recovery) treatment with $5 \mu \mathrm{M}$ AA for 30 sec, and the currents were recorded with a two-electrode voltage clamp. A rinse period of $2 \mathrm{~min}$ was allowed prior to the recovery test. The divalent cations present in the extracellular solution were either $2 \mathrm{~mm}$ calcium $(A)$ or $2 \mathrm{~mm}$ barium $(B)$ substituted for the calcium to prevent possible induction of calcium-activated currents. In both solutions AA reversibly blocked most of the ACh-induced current.

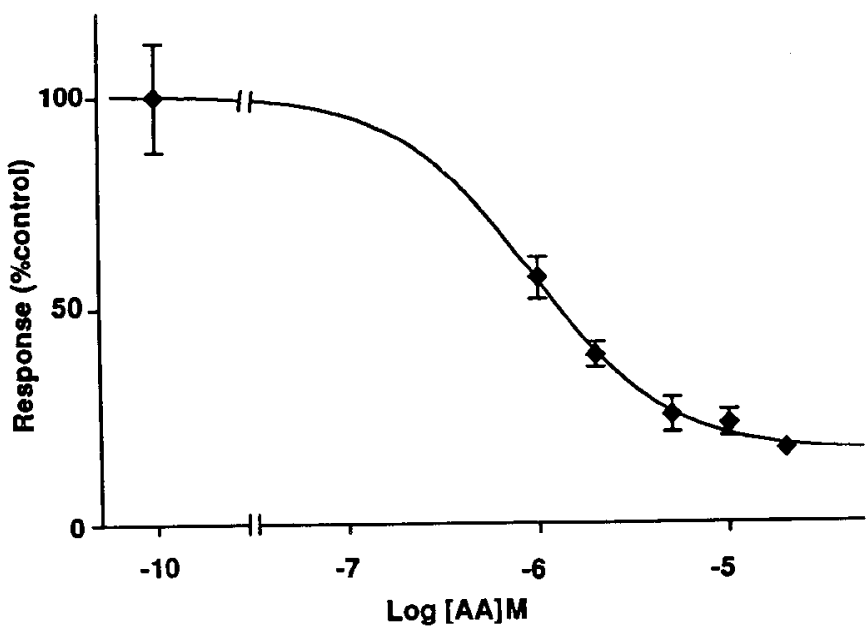

Figure 6. Concentration dependence of AA effects on $\alpha 7$-containing AChRs in oocytes. The peak responses induced by $100 \mu \mathrm{M} \mathrm{ACh}$ in oocytes expressing $\alpha 7$-containing AChRs and treated with the indicated concentrations of AA as described in Figure 5 were measured and expressed as a percent of the initial response obtained from the same oocyte in the absence of AA. Barium ( $2 \mathrm{~mm}$ ) replaced calcium in the extracellular solution. Results are expressed as the mean \pm SEM of 8 20 oocytes per value. AA potently inhibits the ACh-induced currents with an $\mathrm{IC}_{50}$ of about $1 \mu \mathrm{M}$.
Linolenic acid was also tested on chick ciliary ganglion neurons for inhibition of the responses elicited by $10 \mu \mathrm{M}$ nicotine. A $10 \mathrm{sec}$ application of the fatty acid at $20 \mu \mathrm{M}$ reduced the mean peak nicotinic response to $17 \pm 6 \%$ of that obtained from the same neurons before the application ( $\perp$ SEM, $n=10$ cells). A 2 min rinse allowed the response to recover to $66 \pm 5 \%$ of the initial response. AA tested on other neurons in the same experiments under the same conditions reduced the mean peak response to $5 \pm 1 \%$ ( $n=14$ cells $)$. The fact that linolenic acid can partially duplicate the inhibition achieved by AA both with $\alpha 7$-containing receptors expressed in oocytes and with ciliary ganglion $\alpha$ Bgt-AChRs indicates that the mechanism is not confined to $\mathrm{AA}$, and therefore not likely to result from $\mathrm{AA}$-specific metabolites such as prostaglandins or 5-/or 15-hydroxyeicosatetraenoic acids or their hydroperoxy derivatives.

Mechanism of AA effect on nicotinic responses. AA may regulate ionic currents either directly or via breakdown products. In the case of calcium currents in hippocampal neurons, AA exerts a modulatory effect by acting through oxygen radicals and protein kinase C (PKC; Keyser and Alger, 1990). To test whether similar mechanisms accounted for the effect of AA on nicotinic responses from ciliary ganglion neurons, the enzyme superoxide dismutase (SOD) was included in the AA solution $(25 \mathrm{U} / \mathrm{ml})$ and in the recording pipette $(100 \mathrm{U} / \mathrm{ml})$ to dialyze the 


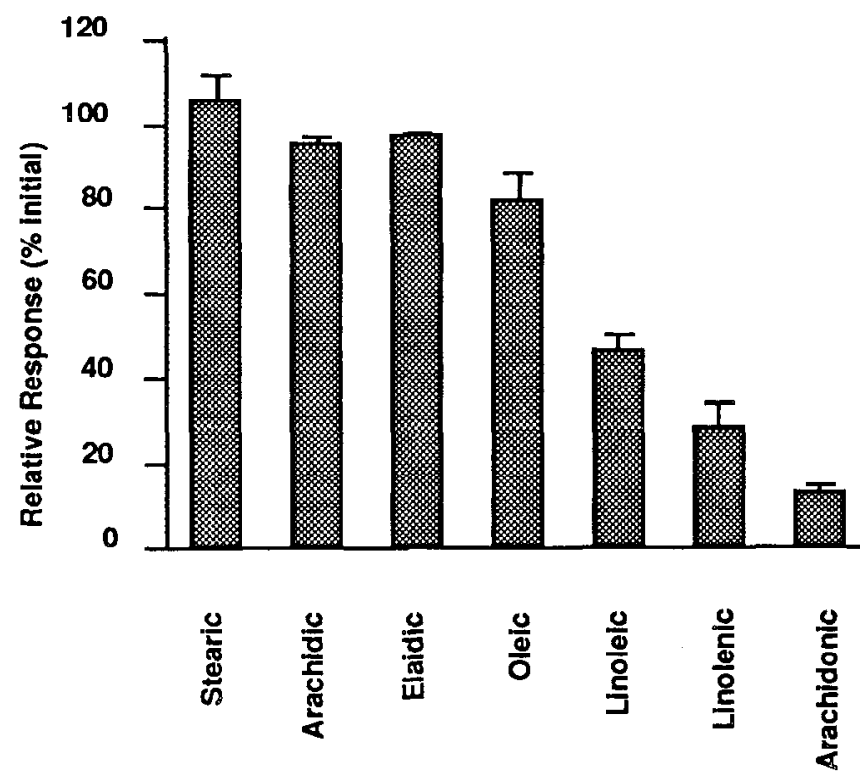

Figure 7. Fatty acids tested for inhibition of $\alpha 7$-containing AChRs in oocytes. Oocytes expressing $\alpha 7$-containing receptors were tested for $\mathrm{ACh}$ responses in the presence and absence of the indicated fatty acid as described for AA in Figure 5. All fatty acids were applied for $30 \mathrm{sec}$ at $20 \mu \mathrm{M}$. Barium at $2 \mathrm{~mm}$ was used to replace calcium in the extracellufar solution. Results have been normalized to initial ACh responses from the same oocytes prior to treatment with the fatty acid and are expressed as the mean \pm SEM of 7-12 oocytes. For the seven fatty acids tested (left to right), the carbon chain lengths, numbers of double bonds, and cis-trans configurations are 18:0; 20:0; 18:1, trans; 18:1, cis; $18: 2$, cis; $18: 3$, cis; $20: 4$, cis, respectively. The ability of fatty acids to inhibit the ACh response correlates well with the number of double bonds they contain.

interior of the cell. Responses to $10 \mu \mathrm{M}$ nicotine were then elicited from cells before and $5 \mathrm{sec}$ after a $10 \mathrm{sec}$ exposure to $5 \mu \mathrm{M}$ AA. The results indicate that SOD provides no protection. The mean response remaining after $A A$ treatment was $41 \pm 2 \%$ in the presence of SOD and $41 \pm 3 \%$ in the absence of SOD (seven cells each; three experiments).

The possibility that PKC was required for the inhibition was tested by including $75 \mu \mathrm{M} \mathrm{H} 7$, an inhibitor of PKC and other protein kinases, in the recording pipette and $\mathrm{AA}$ solution. The $\mathrm{PKC}$ inhibitor was also without effect. The mean response remaining after $\mathrm{AA}$ treatment was $44 \pm 4 \%$ in the presence of $\mathrm{H} 7$ and $40 \pm 3 \%$ in its absence (seven or eight cells each; two experiments). The results do not support a role for either free radicals or $\mathrm{PKC}$ in the $\mathrm{AA}$-mediated inhibition of neuronal AChRs.

\section{Discussion}

The major findings reported here are that activation of neuronal AChRs stimulates release of $\mathrm{AA}$, and that $\mathrm{AA}$, in turn, can reversibly inhibit the receptors. This represents, to our knowledge, the first demonstration of nicotine-induced AA release and the first case of AA inhibiting a ligand-gated ion channel responsible for its production. The results are consistent with a ncgative feedback capability in which AA limits the ability of AChRs to sustain high calcium levels in neurons whether the calcium enters directly through the receptors or indirectly through VDCCs activated by the receptors.

The amount of ${ }^{3} \mathrm{H}-\mathrm{AA}$ release caused by nicotinic stimulation, expressed as a percent of the total labeled AA incorporated, was comparable to that reported previously for stimulation of glutamate receptors on striatal and hippocampal neurons in culture (Dumuis et al., 1988, 1990; Sanfeliu et al., 1990). There are no reliable estimates for the concentration of free AA likely to result at synapses. One report has quantified the total amount of $\mathrm{AA}$ in brain slices and determined the proportion released by stimulation (Clements et al., 1991). If the total amount of AA present in ciliary ganglion neurons per milligram of protein is comparable to that in hippocampal slices, and if labeled and unlabeled AA are released from the neurons with equivalent efficiency, estimates can be provided for the amount of free AA generated per neuron by the nicotinic stimulation used here. Justification for this assumption comes from the observation that hippocampal and ciliary ganglion neurons in culture release similar amounts (\%) of labeled AA using the same assay techniques and times of stimulation. (Most of the cells in ciliary ganglion cultures are neurons and essentially all of them are sensitive to nicotine.) The amount released per neuron would produce a peak concentration of about $400 \mu \mathrm{M}$ were it confined to a space equivalent to the cell volume. Even allowing for a 100 -fold dilution of the peak concentration through diffusion results in a predicted AA concentration sufficient to exert significant inhibition of neuronal AChRs.

It is noteworthy that the AA effect was most pronounced on $\alpha B g t-A C h R s$, having an $\mathrm{EC}_{50}$ of about $1 \mu \mathrm{M}$. Significant inhibition was achieved by $\mathrm{AA}$ at concentrations and/or times of exposure substantially below that reported for most other targets of AA action (Ordway et al., 1989; Williams et al., 1989; Keyser and Alger, 1990; Miller et al., 1992; Damron et al., 1993; Fraser et al., 1993; Schaechter and Benowitz, 1993). Like $\alpha 7$-containing AChRs expressed in Xenopus oocytes (Bertrand et al., 1993; Seguela et al., 1993), the $\alpha$ Bgt-AChRs are likely to have a relatively high calcium permeability. Preferential inhibition of $\alpha 7$-containing receptors could arguably be most essential for limiting the effects of nicotinic signaling on perturbation of intracellular calcium levels. It is interesting that AA does not completely block the responses of $\alpha 7$-containing AChRs in oocytes. Either the oocytes produce a resistant subpopulation of receptors which differ from $\alpha \mathrm{Bgt}$-AChRs in ciliary ganglion neurons, or barium prevents a complete collapse of receptor function.

The mechanism by which AA inhibits neuronal AChRs is unknown. Apparently the $\alpha 7$ gene product alone is sufficient to produce a receptor susceptible to the inhibition. The possibility that specific metabolites of AA are involved as intermediaries in the effect can be ruled out since other fatty acids were able to mimic AA both in ciliary ganglion neurons and in oocytes expressing the $\alpha 7$ gene product. In the case of hippocampal cells, AA inhibits voltage-gated calcium currents though a mechanism that depends both on the production of free radicals and on the activity of PKC (Keyser and Alger, 1990). The requirement for free radicals was demonstrated by showing that SOD prevented the AA-mediated inhibition. The dependence on PKC was demonstrated by showing that injection of a specific peptide inhibitor of $\mathrm{PKC}$ into the cells blocked the AA effect. In the present experiments neither SOD nor $\mathrm{H} 7$, a membrane-permeant inhibitor of $\mathrm{PKC}$, provided any protection against the inhibition of neuronal AChRs by AA. AA appears to exert its effects on AChRs through mechanisms different from those responsible for inhibition of voltage-gated calcium currents.

A different example of AA modulating ligand-gated ion channels is provided by NMDA receptors. In this case the modulation involves a potentiation rather than an inhibition of receptor func- 
tion (Miller ct al., 1992). Bccausc kinase blockers had no effect on the inhibition, the fatty acid was postulated to act either directly on the NMDA receptor or indirectly by perturbing the lipid environment of the receptors. It is possible that similar molecular mechanisms are utilized by AA in modulating neuronal $A C h R s$, though the effect is one of inhibition rather than potentiation. The kinetics of AA-mediated effects on nicotinic receptors are consistent with AA binding either directly to the receptor or dissolving into the membrane in sufficient concentration to alter the lipid environment of the receptors. The time course of reversibility is also consistent with this mode of action, but no direct evidence exists at present to support the contention.

It is of interest that AA achieves a potentiation of NMDA receptors even though the fatty acid can generate oxygen radicals in the same cell type (Lafon-Cazal et al., 1993). Free radicals inhibit NMDA receptors rather than enhance them. The inhibition is thought to be exerted at a site on the receptors sensitive to sulfhydryl redox agents (Aizenman et al., 1990). Apparently the inhibition, if it occurs in situ, is overcome by the potentiating effect. Neuronal AChRs also have sites sensitive to sulfhydryl reagents (Froehner et al., 1977; Damle et al., 1978; Leprince, 1983; Stollberg et al., 1986), presenting a possible target for free radicals. The inability of SOD to protect AChRs against $A A$ indicates that, as with NMDA receptors, free radical production is not likely to produce the modulation observed.

Release of AA would be expected to have a number of consequences in addition to causing negative feedback regulation of AChRs. The compound has been proposed as a transynaptic regulator with effects ranging from control of transmitter release to modulation of membrane currents (Piomelli et al., 1987; Kim and Clapham, 1989; Ordway et al., 1989; Keyser and Alger, 1990; Piomelli and Greengard, 1990; Schweitzer et al., 1990; Ordway et al., 1991; Harish and Poo, 1992; Shimada and Som lyo, 1992; Fraser et al., 1993). By manipulating intracellular calcium levels and AA release, $\alpha \mathrm{Bgt}$-AChRs have the potential for activating regulatory cascades that influence a vast array of cellular events. How such receptors are utilized in the nervous system will be important to resolve.

\section{References}

Aizenman E, Hartnett KA, Reynolds IJ (1990) Oxygen free radicals regulate NMDA receptor function via a redox modulatory site. Neuron 5:841-846.

Ballivet M, Nef P, Couturier S, Rungger D, Bader CR, Bertrand D, Cooper E (1988) Electrophysiology of a chick neuronal nicotinic acetylcholine receptor expressed in Xenopus oocytes after cDNA injection. Neuron 1:847-852.

Barish ME (1983) A transient calcium-dependent chloride current in the immature Xenopus oocyte. J Physiol (Lond) 342:309-325.

Bertrand D, Galzi JL, Devillers-Thiery A. Bertrand S, Changeux JP (1993) Mutations at two distinct sites within the channel domain M2 alter calcium permeability of neuronal $\alpha 7$ nicotinic receptor. Proc Natl Acad Sci USA 90:6971-6975.

Chan J, Quik M (1993) A role for the nicotinic $\alpha$-bungarotoxin receptor in neurite outgrowth in PC12 cells. Neuroscience 56:441-451.

Chiappinclli VA, Giacobini L (1978) Time course of appearance of $\alpha$-bungarotoxin binding sites during development of chick ciliary ganglion and iris. Neurochem Res 3:465-478.

Chiappinelli V, Giacobini E, Pilar G, Uchimura H (1976) Induction of cholinergic enzymes in chick ciliary ganglion and iris muscle cells during synapse formation. J Physiol (Lond) 257:749-766.

Clarke PBS, Pert A (1985) Autoradiographic evidence for nicotine receptors on nigrostriatal and mesolimbic dopaminergic neurons. Brain Res 348:355-358.

Clements MP, Bliss TVP, Lynch MA (1991) Increase in arachidonic acid concentration in a postsynaptic membrane fraction following the induction of long-term potentiation in the dentate gyrus. Neuroscience 45:379-389.

Damle VN, McLaughlin M, Karlin A (1978) Bromoacetylcholine as an affinity label of the acetylcholine receptor from Torpedo californica. Biochem Biophys Res Commun 84:845-851.

Damron DS, Van Wagoner DR, Moravec CS, Bond M (1993) Arachidonic acid and endothelin potentiate $\mathrm{Ca}^{2+}$ transients in rat cardiac myocytes via inhibition of distinct $\mathrm{K}^{+}$channeis. J Biol Chem 268: $27335-27344$.

Dumuis A, Sebben M, Haynes L, Pin J-P, Bockaert J (1988) NMDA receptors activate the arachidonic acid cascade system in striatal neurons. Nature 336:68-70.

Dumuis A, Pin J-P, Oomagari K, Sebben M, Bockaert J (1990) Arachidonic acid released from striatal neurons by joint stimulation of ionotropic and metabotropic quisqualate receptors. Nature 347:182184.

Ferrer-Montiel AV, Montal M (1993) A negative charge in the M2 transmembrane segment of the neuronal $\alpha 7$ acetylcholine receptor increases permeability to divalent cations. FEBS Lett 324:185-190.

Fieber LA, Adams DA (1991) Acetylcholine-evoked currents in cultured neurones dissociated from rat parasympathetic cardiac ganglia. J Physiol (Lond) 434:215-237.

Fraser DD, Hoehn K, Weiss S, MacVicar BA (1993) Arachidonic acid inhibits sodium currents and synaptic transmission in cultured striatal neurons. Neuron 11:633-644.

Froehner SC, Karlin A, Hall ZW (1977) Affinity alkylation labels two subunits of the reduced acetylcholine receptor from mammalian muscle. Proc Natl Acad Sci USA 74:4685-4688.

Galzi J-L, Devillers-Thiery A, Hussy N, Bertrand S, Changeux J-P, Bertrand D (1992) Mutations in the channel domain of a neuronal nicotinic receptor convert ion selectivity from cationic to anionic. Nature 359:500-505.

Greenberg ME, Ziff EB, Greene LA (1986) Stimulation of neuronal acetylcholine receptors induces rapid gene transcription. Science 234: $80-83$.

Grossman S, Schon I, Sofer Y, Magid N, Bartoov B (1986) Arachidonic acid metabolizing enzymes in the ram reproductive system. In: Advances in prostaglandins, thromboxane and leukotriene research, Vol 16 (Zor U, Naor Z, Kohen F, eds), pp 241-252. New York: Raven.

Halvorsen SW, Berg DK (1987) Affinity labeling of neuronal acetylcholine receptor subunits with an $\alpha$-neurotoxin that blocks receptor function. J Neurosci 7:2547-2555.

Hamill OP, Marty A, Neher E, Sakmann B, Sigworth FJ (1981) Improved patch-clamp techniques for high-resolution current recordings from cells and cell-free membrane patches. Pfluegers Arch 391:85100.

Harish OE, Poo M-M (1992) Retrograde modulation at developing neuromuscular synapses: involvement of $G$ protein and arachidonic acid cascade. Neuron 9:1201-1209.

Jacob MH, Berg DK (1983) The ultrastructural localization of $\alpha$ bun garotoxin binding sites in relation to synapses on chick ciliary ganglion neurons. J Neurosci 3:260-271.

Jacob MH, Berg DK, Lindstrom JM (1984) Shared antigenic determinant between the Electrophorus acetylcholine receptor and a synaptic component on chicken ciliary ganglion neurons. Proc Natl Acad Sci USA 81:3223-3227.

Keyser DO, Alger BE (1990) Arachidonic acid modulates hippocampal calcium current via protein kinase $\mathrm{C}$ and oxygen radicals. Neuron $5: 545-553$.

Kim D, Clapham DE (1989) Potassium channels in cardiac cells activated by arachidonic acid and phospholipids. Science 244:1174 1176.

Lafon-Cazal M, Pietri S, Culcasi M, Bockaert J (1993) NMDA-dependent superoxide production and neurotoxicity. Nature 364:535-537.

Lax Y, Grossman S, Rubinstein S, Magid N, Breitbart H (1990) Role of lipoxygenase in the mechanism of acrosome reaction in mammalian spermatozoa. Biochim Biophys Acta 1043:12-18.

Lena C, Changeux J-P, Mulle C (1993) Evidence for "preterminal" nicotinic receptors on GABAergic axons in the rat interpeduncular nucleus. J Neurosci 13:2680-2688.

Leprince $\mathrm{P}$ (1983) Chemical modification of the nicotinic cholinergic receptor of PC- 12 nerve cell. Biochemistry 22:5551-5556

Loring RH, Zigmond RE (1987) Ultrastructural distribution of ${ }^{125}$ Itoxin $\mathrm{F}$ binding sites on chick ciliary neurons: synaptic localization 
of a toxin that blocks ganglionic nicotinic receptors. J Ncurosci 7:2153-2162.

Loring RH, Chiappinelli VA, Zigmond RE, Cohen JB (1984) Characterization of a snake venom neurotoxin which blocks nicotinic transmission in the avian ciliary ganglion. Neuroscience 11:989-999.

Loring RH, Dahm LM, Zigmond RE (1985) Localization of $\alpha$-bungarotoxin binding sites in the ciliary ganglion of the embryonic chick: an autoradiographic study at the light and electron microscopic level. Neuroscience 14:645-660.

Margiotta JF, Gurantz D (1989) Changes in the number, function, and regulation of nicotinic acetylcholine receptors during neural development. Dev Binl 135:326-339.

Miller B, Sarantis M, Traynelis SF, Attwell D (1992) Potentiation of NMDA receptor currents by arachidonic acid. Nature 355:722-725.

Mulle C, Vidal C, Benoit P, Changeux J-P (1991) Existence of different subtypes of nicotinic acetylcholine receptors in the rat habenulo-interpeduncular system. J Neurosci 11:2588-2597.

Mulle C, Choquel D, Korn H, Changeux J-P (1992) Calcium influx through nicotinic receptor in rat central neurons: its relevance to cellular regulation. Neuron 8:135-143.

Nishi R, Berg DK (1981) Two components from eye tissue that differentially stimulate the growth and development of ciliary ganglion neurons in cell culture. $\mathbf{J}$ Neurosci 1:505-513.

Ordway RW, Walsh JV Jr, Singer JJ (1989) Arachidonic acid and other fatty acids directly activate potassium channels in smooth muscle cells. Science 244:1176-1179

Ordway RW, Singer.JJ, Walsh JV Jr (1991) Direct regulation of ion channels by fatty acids. Trends Neurosci 14:96-100.

Piomelli D, Greengard P (1990) Lipoxygenase metabolites of arachidonic acid in neuronal transmembrane signaling. Trends Pharmacol Sci 11:367-373.

Piomelli D, Volterra A, Dale N, Siegelbaum SA, Kandel ER, Schwartz JH, Belardetti F (1987) Lipoxygenase metabolites of arachidonic acid as second messengers for presynaptic inhibition of Aplysia sensory cells. Nature 328:38-43.

Pugh PC, Berg DK (1994) Neuronal acetylcholine receptors that bind $\alpha$-bungarotoxin mediate neurite retraction in a calcium-dependent manner. J Neurosci 14:889-896.

Rapier C, Lunt GG, Wonnacott S (1990) Nicotinic modulation of ${ }^{3} \mathrm{H}-$ dopamine release from striatal synaptosomes: pharmacological characterisation. J Neurochem 54:937-945.

Ravdin PM, Berg DK (1979) Inhibition of neuronal acetylcholine sensitivity by $\alpha$-toxins from Bungarus multicinctus venom. Proc Natl Acad Sci USA 76:2072-2076.

Sands SB, Barish ME (1991) Calcium permeability of neuronal nicotinic acetylcholine receptor channels in PC12 cells. Brain Res 560: $38-42$.

Sands SB, Costa ACS, Patrick JW (1993) Barium permeability of neuronal nicotinic receptor $\alpha 7$ expressed in Xenopus oocytes. Biophys $\mathbf{J}$ $65: 2614-2621$.
Sanfeliu C, IIunt A, Patel AJ (1990) Exposure to $N$-methyl-D-aspartate increases release of arachidonic acid in primary cultures of rat hippocampal neurons and not in astrocytes. Brain Res 526:241-248.

Sargent PB (1993) The diversity of neuronal nicotinic acetylcholine receptors. Annu Rev Neurosci 16:403 443.

Schaechter JD, Benowitz LI (1993) Activation of protein kinase C by arachidonic acid selectively enhances the phosphorylation of GAP43 in nerve terminal membranes. J Neurosci 13:4361-4371.

Schoepfer R, Conroy WG, Whiting P. Gore M. Lindstrom J (1990) Brain $\alpha$-bungarotoxin binding protein cDNAs and mAbs reveal subtypes of this branch of the ligand-gated ion channel gene superfamily. Neuron 5:35-48.

Schulz DW, Zigmond RE (1989) Neuronal bungarotoxin blocks the nicotinic stimulation of endogenous dopamine release from rat striatum. Neurosci Lett 98:310-316.

Schweitzer P, Madamba S, Siggins GR (1990) Arachidonic acid metabolites as mediators of somatostatin-induced increase of neuronal M-current. Nature 346:464-467.

Seguela P, Wadiche J, Dineley-Miller K, Dani JA, Patrick JW (1993) Molecular cloning, functional properties, and distribution of rat brain $\alpha 7$ : a nicotinic cation channel highly permeable to calcium. J Neurosci 13:596-604.

Shimada T, Somlyo AP (1992) Modulation of voltage-dependent Ca channel current by arachidonic acid and other long-chain fatty acids in rabbit intestinal smooth muscle. J Gen Physiol 100:27-44.

Stollberg J, Whiting PJ, Lindstrom JM, Berg DK (1986) Functional blockade of neuronal acetylcholine receptors by antisera to a putative receptor from brain. Brain Res 378:179-182.

Trouslard J, Marsh SJ, Brown DA (1993) Calcium entry through nicotinic receptor channels and calcium channels in cultured rat superior cervical ganglion cells. J Physiol (Lond) 468:53-71.

Van der Kloot W (1993) Nicotinic agonists antagonize quantal size increases and evoked release at frog neuromuscular junction. J Physiol (Lond) 468:567-589.

Vernallis AB, Conroy WG, Berg DK (1993) Neurons assemble acetylcholine receptors with as many as three kinds of subunits while maintaining subunit segregation among receptor subtypes. Neuron $10: 451-464$.

Vernino S, Amador M, Luetje CW, Patrick J, Dani JA (1992) Calcium modulation and high calcium permeability of neuronal nicotinic acetylcholine receptors. Neuron 8:127-134.

Vijayaraghavan S, Pugh PC, Zhang Z-w, Rathouz MM, Berg DK (1992) Nicotinic rcceptors that bind $\alpha$-bungarotoxin on neurons raise intracellular free $\mathrm{Ca}^{2+}$. Neuron 8:353-362.

Williams JH, Errington ML, Lynch MA, Bliss TVP (1989) Arachidonic acid induces a long-term activity-dependent enhancement of synaptic transmission in the hippocampus. Nature 341:739-742.

Zhang Z-w, Vijayaraghavan S, Berg DK (1994) Neuronal acetylcholine receptors that bind $\alpha$-bungarotoxin with high affinity function as ligand-gated ion channels. Neuron 12:167-177. 